\title{
Conceptus development in Large White and prolific Chinese Meishan pigs
}

\author{
F. W. Bazer, W. W. Thatcher*, F. Martinat-Botte $\dagger$ and M. Terqui $\ddagger$
}

Departments of Animal Science and *Dairy Science, University of Florida, Gainesville, Florida, 32611, U.S.A.; †Institut Technique du Porc, 149 rue de Bercy, 75595 Paris-Cedex 12, France; and $\ddagger$ Laboratoire de Physiologie de la Reproduction and Institut National Recherche Agronomique, Nouzilly 37380, France

Summary. Large White (LW) and Meishan (MS) gilts were killed on Days 8, 10, 11, 12, 14 and 30 of gestation. Mean diameters $(\mathrm{mm})$ for MS and LW conceptuses, respectively, were: Day 8, 0.45 and 0.69; Day 10, 2.7 and 1.9; Day 11, 5.3 and 2.7, with the differences among days being affected by breed $(P<0.01)$. Variation in diameter among conceptuses from LW gilts was greater $(P<0.01)$ than that for MS gilts on Days 8-11, respectively: Day 8, 20 and 46\%; Day 10,29 and 38\%; and Day 11, 22 and $44 \%$. Conceptuses had elongated in 3 of 5 MS and 1 of 4 LW gilts on Day 11, 6 and 6 MS and 2 of $4 \mathrm{LW}$ gilts on Day 12 and all gilts of both breeds on Day 14. These results indicate that conceptuses of MS gilts develop more rapidly and more uniformly between Days 8 and 14 of gestation. Overall, embryonic survival for Days 8-12 for gilts not having elongated conceptuses was $90 \cdot 2 \%$ for MS and $73.2 \%$ for LW gilts $(P<0.01)$. On Day 30 of gestation, embryonic survival was also higher $(P<0.01)$ for MS $(89 \%)$ than LW $(55 \%)$ gilts. However, embryonic weight, crown-rump length, placental length, allantoic fluid volume, amniotic fluid volume, as well as total glucose, fructose and protein in allantoic fluid were not affected by breed. Placental weight was greater $(P<0.01)$ for LW gilts. Uterine development at Day 30 of gestation, based on total length and weight of uterine horns, width of uterine horns, total endometrial surface area and total endometrial weight was greater $(P<0.01)$ for LW gilts. Ovulation rates on Days 8-14 and on Day 30 were also higher $(P<0.05)$ for $\mathrm{LW}$ gilts. These results indicate that: (1) ovulation rates were lower and uteri were smaller for prolific MS gilts; (2) faster and more uniform conceptus development between Days 8 and 14 of gestation for MS gilts was associated with higher embryonic survival; and (3) embryos and placentae surviving to Day 30 had similar weights and lengths, but embryonic survival to Day 30 of gestation was higher for MS gilts. Factors regulating rate and uniformity of conceptus development in swine may be primary determinants of prolificacy.

Keywords: pig; conceptus; Chinese; uterus; pregnancy

\section{Introduction}

Bidanel \& Legault (1986) reported that females of the Meishan breed of pig from the People's Republic of China are highly prolific compared to females of the Large White breed due to low rates of embryonic mortality for Meishan sows and not to differences in ovulation rate. Identification and study of prolific breeds of pigs is important scientifically since we know that litter size has changed very little since Sir John Hammond (1914, 1921) first established the relationship between ovulation rate and litter size and determined that embryonic-fetal death losses claimed $25-50 \%$ of 
potential offspring in breeds of pigs commonly used for meat production. In the intervening years, genetic selection within breed or utilization of cross-breeding systems have resulted in increases of only 1-1.5 piglets born per litter (see Legault, 1985). Litter size in pigs is dependent upon ovulation rate, fertilization rate of ova ovulated, embryonic survival and uterine capacity (Wrathall, 1971; Bazer \& First, 1983). Ovulation rate can be regulated through genetic selection or the use of exogenous gonadotrophins. Fertilization rates are $95 \%$ or higher in swine. However, embryonic mortality is considered the major limitation to increasing litter size in this species. Uterine capacity refers to physical limitations of the uterine endometrial surface area as well as to biochemical, physiological and endocrinological limitations which may render uteri of some individuals, breeds or strains less competent to accommodate large litters for the duration of pregnancy. In this study we compared conceptus development in Large White and Meishan gilts to determine differences in: (1) ovulation rate; (2) conceptus development and survival between Days 8 and 14 and on Day 30 of gestation; and (3) embryonic-placental development and fetal fluid volumes on Day 30 of gestation.

\section{Materials and Methods}

Gilts (31 Meishan and 27 Large White) were assigned randomly to provide data on conceptus development on Days 8 , $10,11,12,14$ and 30 of gestation. Gilts were inseminated artificially at 24 and $36 \mathrm{~h}$ or at 12 and $24 \mathrm{~h}$ after onset of oestrus for Meishan and Large White gilts, respectively. The difference in times of insemination was to account for the fact that Meishan gilts exhibit oestrus for $70 \pm 15 \mathrm{~h}$ compared to $42 \pm 12 \mathrm{~h}$ for Large White gilts (F. Martinat-Botte, unpublished data). All gilts had experienced at least 3 oestrous cycles before being inseminated (see Bazer et al., 1988). Reproductive tracts were obtained immediately after slaughter and kept on ice until uterine flushings could be obtained to recover conceptuses (Geisert et al., 1982) or the conceptuses could be individually recovered on Day 30 as described by Knight $e t$ al. (1977). Uterine flushings were examined using a dissecting microscope fitted with an eyepiece micrometer to identify and determine the diameter of each conceptus which was in the spherical or tubular form (Geisert et al., 1982). Because experimental protocol required that uterine flushings be obtained for analyses, filamentous conceptuses were not obtained individually for measurement. However, on Day 14 of pregnancy, total wet weight of conceptus tissue recovered from each uterine horn was determined.

Length of the uterine horns was measured directly and weight of the uterus was determined after obtaining uterine flushings or removing conceptuses. Width of one uterine horn was determined at points about $10 \mathrm{~cm}$ above the uterine body, $10 \mathrm{~cm}$ below the utero-tubal junction and in the middle of the uterine horn. Average uterine width was multiplied by uterine length to estimate endometrial surface area. Sections of uterus were taken from the same areas of one randomly selected uterine horn and weighed, then the endometrium was dissected free of myometrium and serosa and weighed. Weight of endometrium alone divided by weight of its respective uterine section was used to estimate percentage of uterus represented by endometrium. Total uterine weight multiplied by percentage endometrium was used to estimate total endometrial weight.

On Day 30 of pregnancy, each conceptus was removed from the uterus by dissection (Knight et al., 1977). Individual allantoic fluid samples of $10 \mathrm{ml}$ each were obtained from all conceptuses from 3 litters of each breed and analysed for concentrations of protein (Lowry et al., 1951), glucose (Zavy et al., 1982) and fructose (Roe, 1934). Total allantoic fluid volume was measured directly in a graduated cylinder and multiplied by concentrations of protein, glucose and fructose to determine total protein, glucose and fructose for each allantoic sac. Amniotic fluid volume was measured by withdrawing the fluid directly into a graduated $5-\mathrm{ml}$ syringe connected to a 20 -gauge needle. Placental length was measured directly and placental weight was determined on an analytical balance.

Data were analysed by least squares analysis of variance to detect main effects of breed, day of gestation and breed by day of gestation interactions on morphological development of spherical and tubular conceptuses between Days 8 and 12 of gestation. Heterogeneity of variation in conceptus development between breeds was also determined (Steel \& Torrie, 1960). $\chi^{2}$ tests were used to detect differences in embryonic survival. Effects of breed on uterine development as well as conceptus development and fetal fluid volumes and composition at Day 30 of gestation were determined using least squares analysis of variance. The statistical model also included body weight at slaughter on Day 30 of pregnancy as a covariate to further evaluate differences in morphological development of the uterus.

\section{Results}

Conceptuses from Large White gilts were larger in diameter than those from Meishan gilts on Day 8, but on Days 10-12 conceptuses of Meishan gilts were larger (Table 1). This resulted in a day-bybreed interaction $(P<0.01)$ indicating that the pattern of development of conceptuses differed 
between breeds during that period. Variation in size of conceptuses recovered on Days 8-12 was also less $(P<0.01)$ for Meishan gilts, indicating that conceptuses from these gilts not only developed faster, but also more uniformly.

Table 1. Conceptus development in Chinese Meishan (MS) and Large White (LW) gilts between Days 8 and 14 of gestation

\begin{tabular}{|c|c|c|c|c|c|c|c|c|c|c|}
\hline & \multicolumn{10}{|c|}{ Day of gestation } \\
\hline & \multicolumn{2}{|c|}{8} & \multicolumn{2}{|c|}{10} & \multicolumn{2}{|c|}{11} & \multicolumn{2}{|c|}{12} & \multicolumn{2}{|c|}{14} \\
\hline & MS & LW & MS & LW & MS & LW & MS & LW & MS & LW \\
\hline Gilts pregnant & 4 & 4 & 4 & 4 & 5 & 4 & 6 & 4 & 4 & 4 \\
\hline Conceptus diam. $(\mathrm{mm})^{*}$ & $\begin{array}{r}0.45 \\
\pm 0.1\end{array}$ & $\begin{array}{r}0.69 \\
\pm 0.3\end{array}$ & $\begin{array}{r}2.7 \\
\pm 0.8\end{array}$ & $\begin{array}{r}1.9 \\
\pm 0.7\end{array}$ & $\begin{array}{r}5 \cdot 3 \\
\pm 1.2\end{array}$ & $\begin{array}{r}2.7 \\
+1.2\end{array}$ & $\frac{\mathrm{E}^{\dagger}}{-}$ & $\begin{array}{r}9.8 \dagger \\
+1.1\end{array}$ & $\mathrm{E}^{\dagger}$ & $\underline{\mathrm{E} \dagger}$ \\
\hline $\begin{array}{l}\text { Coefficient of variation } \\
\text { for conceptus diam. } \\
(\%) \ddagger\end{array}$ & 20 & 46 & 29 & 38 & 22 & 42 & - & - & - & - \\
\hline $\begin{array}{l}\text { No. of gilts with } \\
\text { filamentous } \\
\text { conceptuses }\end{array}$ & 0 & 0 & 0 & 0 & 3 & 0 & 6 & 2 & 4 & 4 \\
\hline Embryonic survival $(\%) \S$ & 89 & 82 & 86 & 83 & 100 & 48 & ND & ND & ND & ND \\
\hline
\end{tabular}

Values are mean \pm s.e.m.

*Day $\times$ breed interaction $(P<0.01)$.

†Conceptuses were elongated in all MS gilts which precluded further comparison of diameter conceptuses. For LW gilts, conceptus diameters are for those from 2 gilts in which elongation has not occurred.

$\ddagger$ Variation was less $(P<0.01)$ for MS conceptuses.

$\S$ Calculated as conceptuses recovered divided by number of corpora lutea and expressed as percentage. For Days 8-11, overall embryonic survival was higher $(P<0.01)$ for MS $(90 \cdot 2 \%)$ than LW $(73 \cdot 2 \%)$ gilts.

Conceptuses had elongated in 3 of 5 Meishan, but only 1 of 4 Large White gilts on Day 11, 6 of Meishan and 2 of 4 Large White gilts on Day 12 and all gilts of both breeds on Day 14. Differences in time of elongation also indicated that conceptuses from Meishan gilts were developing more rapidly. Embryonic survival in gilts having conceptuses that had not elongated on Days 8-11 was higher for Meishan $(90 \cdot 2 \%)$ than Large White $(73 \cdot 2 \%)$ females.

Table 2. Reproductive performance of Chinese Meishan (MS) and Large White (LW) gilts at Day 30 of gestation

\begin{tabular}{|c|c|c|}
\hline & \multicolumn{2}{|c|}{ Breed } \\
\hline & MS & LW \\
\hline No. gilts & 8 & 7 \\
\hline No. of corpora lutea & $14 \cdot 1 \pm 1 \cdot 2$ & $18 \cdot 5 \pm 1 \cdot 2^{*}$ \\
\hline Wt of corpora lutea (g) & $4 \cdot 6 \pm 0 \cdot 3$ & $4.8 \pm 0.3$ \\
\hline Total ovarian wt (g) & $12 \cdot 7 \pm 0.7$ & $15 \cdot 0 \pm 0.8$ \\
\hline \multicolumn{3}{|l|}{ Embryos } \\
\hline Total & $12 \cdot 9 \pm 1 \cdot 5$ & $11.0 \pm 1.6$ \\
\hline Live & $12 \cdot 4 \pm 1 \cdot 5$ & $10 \cdot 1 \pm 1 \cdot 6$ \\
\hline Dead & $0.5 \pm 0.3$ & $0.9 \pm 0.3$ \\
\hline Embryonic survival (\%) & $\overline{89}$ & $\overline{55 * *}$ \\
\hline
\end{tabular}

Values are mean \pm s.e.m.

${ }^{*} P<0.05 ;{ }^{* *} P<0.01$. 
Table 3. Uterine development at Day 30 of gestation for Chinese Meishan (MS) and Large White (LW) gilts

\begin{tabular}{lcc}
\hline & \multicolumn{2}{c}{ Breed } \\
\cline { 2 - 3 } & MS & LW \\
\hline No. of pigs & 5 & 7 \\
Uterine length (cm) & $330 \pm 25$ & $420 \pm 27^{*}$ \\
Uterine wt (g) & $817 \pm 63$ & $1320 \pm 68^{* *}$ \\
Uterine width (cm) & $6 \cdot 3 \pm 0 \cdot 2$ & $7 \cdot 5 \pm 0 \cdot 2^{* *}$ \\
Endometrial surface & $2086 \pm 172$ & $3281 \pm 185^{* *}$ \\
$\quad$ area $\left(\mathrm{cm}^{2}\right)$ & $298 \pm 30$ & $606 \pm 33^{* *}$ \\
Endometrial wt $(\mathrm{g})$ & $36 \cdot 2 \pm 1 \cdot 8$ & $46 \cdot 1 \pm 1 \cdot 9$ \\
Endometrium $(\%)$ & $89 \pm 7$ & $171 \pm 8^{* *}$ \\
Slaughter wt $(\mathrm{kg})$ & $235 \pm 17$ & $291 \pm 18^{* *}$ \\
Age at slaughter & \\
$\quad$ (days) &
\end{tabular}

Values are mean \pm s.e.m.

${ }^{*} P<0.05 ;{ }^{* *} P<0.01$.

On Day 30, Large White gilts had more CL $(P<0.05)$, but differences in total weight of CL, total ovarian weight, numbers of live, dead or total embryos were not significantly different. However, embryonic survival was higher $(P<0.01)$ for Meishan gilts (Table 2). Age and weight at slaughter, length, weight and width of uterine horns as well as surface area and weight of endometrium were greater for Large White gilts $(P<0.01)$ when weight at slaughter was not considered in the statistical model (see Table 3). When weight at slaughter was included as the covariate in the statistical model, weight of uterus and endometrium were higher for Large White gilts $(P<0.01)$, but breed differences in length and width of uterine horns and endometrial surface area were not significant.

Table 4. Fetal-placental development at Day 30 of gestation in Chinese Meishan (MS) and Large White (LW) gilts

\begin{tabular}{lcc}
\hline & \multicolumn{2}{c}{ Breed } \\
\cline { 2 - 3 } & MS & LW \\
\hline Crown-rump length (mm) & $25 \cdot 3 \pm 0 \cdot 1$ & $25 \cdot 4 \pm 0 \cdot 1$ \\
Embryo wt (g) & $1 \cdot 7 \pm 0 \cdot 3$ & $1 \cdot 6 \pm 0 \cdot 3$ \\
Placental length (cm) & $41 \pm 1$ & $40 \pm 1$ \\
Placental wt.(g) & $184 \pm 8$ & $255 \pm 8^{* *}$ \\
Allantoic fluid (ml) & $181 \pm 6$ & $200 \pm 6^{*}$ \\
Amniotic fluid (ml) & $1 \cdot 6 \pm 0 \cdot 3$ & $1 \cdot 5 \pm 0 \cdot 3$ \\
Allantoic fluid & $227 \pm 12$ & $233 \pm 13$ \\
$\quad$ Total fructose (mg) & $64 \pm 5$ & $63 \pm 5$ \\
Total glucose (mg) & $117 \pm 7$ & $129 \pm 8$ \\
Total protein (mg) & & \\
\hline
\end{tabular}

Values are mean \pm s.e.m. Numbers of observations for fetalplacental measurements were 60 for Meishan and 66 for Large White gilts. Allantoic fluid total fructose, glucose and protein data are based on 35 observations from 3 litters of Meishan gilts and 29 observations from 3 litters of Large White gilts.

$* P<0.05 ;{ }^{* *} P<0.01$. 
Crown-rump length and weight of embryos, length of placentae, amniotic fluid volume and total glucose, fructose and protein in allantoic fluid did not differ between breeds. However, placental weight $(P<0.01)$ and allantoic fluid volume $(P<0.05)$ were greater for Large White gilts (Table 4).

\section{Discussion}

Pig conceptuses are spherical on Days 8 and 10 and undergo transition to large spherical forms of about $10 \mathrm{~mm}$ diameter on Day 10.5, tubular forms of 1-2 mm diameter and $25-50 \mathrm{~mm}$ long on Days 11-12 and the filamentous form on about Day $12(1 \mathrm{~mm}$ diameter and about $200 \mathrm{~mm}$ in length) as reported by Geisert et al. (1982). This transition involves remodelling of trophoblast and a change in length of conceptuses at a rate of $35-40 \mathrm{~mm}$ per hour on Days 11-12. In the present study, conceptuses of Meishan gilts elongated earlier and had less variability in conceptus size for each of the days. These results suggest that Meishan conceptuses are expressing genetic factors which favour rapid and uniform development as well as higher embryonic survival during the period when expected embryonic death losses are greatest. This conclusion is strengthened by the report of Bidanel \& Legault (1986) which indicates that litter size born to $F_{1}$ females resulting from cross-breeding Meishan and Large White breeds ( $15 \cdot 3$ piglets/litter) is greater than that for Large White sows ( 10.7 piglets/litter) or that obtained from crossing hyperprolific Large White sows and Meishan (17.4 piglets/litter) compared to hyperprolific Large White sows (13.1 piglets/litter). Goldbard \& Warner (1982) reported an H-2 associated gene (preimplantation embryonic development, Ped gene) in mice which determines whether mouse embryos have fast, normal or slow rates of development during the preimplantation period. More recently, Warner et al. (1986) reported that there are MHC antigens of the SLA complex on preimplantation (Days 2-6) pig embryos, indicating that a search for a pig Ped gene is warranted.

Day 30 of gestation is suitable for estimating embryonic survival in pigs because each conceptus is distinct and can be easily evaluated as to whether it is normal morphologically. Results from the present study indicated no differences in conceptus development, except for placental weight, between Meishan and Large White gilts. Ovulation rate was higher for Large White gilts, but they also had greater embryonic death losses. Therefore, average litter size favoured Meishan gilts by 2.3 embryos. Although this difference was not significant statistically for the number of gilts available for study on Day 30 of gestation, embryonic survival was significantly greater for Meishan gilts. Total glucose, fructose and protein in allantoic fluid did not differ between breeds. However, morphological development of the uterus was less for Meishan gilts. This suggests that placental function may be more efficient for Meishan gilts since quantity of selected nutrients in allantoic fluid were not different in spite of reduced endometrial surface area for placental exchange.

Results of the present study indicate that factors controlling the rate and uniformity of conceptus development may be primary determinants of prolificacy in Meishan pigs, although the basis for this phenomenon is unknown. The work of Warner et al. (1986) with SLA antigens of the MHC complex may be very important to our understanding of genetic regulation of conceptus development in pigs. It is also possible that quality of oocytes at the time of ovulation may provide an advantage to Meishan gilts. Koenig et al. (1986) reported that pigs selected for increased ovulation rate had higher frequencies of chromosomal abnormalities and oocytes which were meiotically immature. The Meishan female provides a biological model with an inherent genetic capacity to express high prolificacy because of a low rate of embryonic deaths. Once we understand the regulatory determinants of early embryonic development, we may be able to improve reproductive efficiency in breeds of pigs which have high levels of efficiency for both production of animal protein and reproduction. 
We thank the Institut National Recherche Agronomique, the Institute Technique du Porc and the United States Department of Agriculture, Office of International Cooperation and Development for the support of this research; Ms Jan Lauer for help in preparing this manuscript; $\mathrm{Mr}$ Daniel Dubois for data analyses; and Mr P. Despres for excellent management of the experimental gilts. This publication is Journal Series No.8463 of the University of Florida Agricultural Experiment Station.

\section{References}

Bazer, F.W. \& First, N. (1983) Pregnancy and parturition. J. Anim. Sci. 57, Suppl. 2, 425-460.

Bazer, F.W., Thatcher, W.W., Martinat-Botte, F. \& Terqui, M. (1988) Sexual maturation and morphological development of the reproductive tract in Large White and prolific Chinese Meishan pigs. $J$. Reprod. Fert. 83, 723-728.

Bidanel, J.P. \& Legault, C. (1986) Experimental and prospective aspects of the utilization of prolific Chinese pig breeds in Europe. Proc. 37th Meeting Eur. Ass. Anim. Prod. Budapest, vol. 1, 104-105, Abstr.

Geisert, R.D., Brookbank, J.W., Roberts, R.M. \& Bazer, F.W. (1982) Establishment of pregnancy in the pig. II. Cellular remodelling of the porcine blastocyst during elongation on day 12 of pregnancy. Biol. Reprod. 27, 941-955.

Goldbard, S.B. \& Warner, C.M. (1982) Genes affecting the timing of early mouse embryo development. Biol. Reprod. 27, 419-430.

Hammond, J. (1914) On some factors affecting fertility in domestic animals. J. agric. Sci., Camb. 6, 263-277.

Hammond, J. (192I) Further observations on the factors controlling fertility and foetal atrophy. J. agric. Sci., Camb. 11, 337-366.

Koenig, J.L.F., Zimmerman, D.R., Eldridge, F.E. \& Kopf, J.D. (1986) Cytogenetic analysis of swine ova: the effect of superovulation and selection for high ovulation rate. Biol. Reprod. 34, Suppl. 1, 59, abstr.

Knight, J.W., Bazer, F.W., Thatcher, W.W., Franke, D.E. \& Wallace, H.D. (1977) Conceptus development in intact and unilaterally hysterectomized gilts: Interrelationship among hormonal status, placental development, fetal fluids and fetal growth. J. Anim. Sci. 44, 620-637.

Legault, C. (1985) Selection of breeds, strains and individual pigs for prolificacy. J. Reprod. Fert., Suppl. 33, $15 \mathrm{I}-166$.

Lowry, O.H., Rosebrough, N.C., Farr, A.L. \& Randall, R.J. (1951) Protein measurement with the Folin phenol reagent. J. biol. Chem. 193, 266-275.

Roe, J.H. (1934) Colorimetric method for the determination of fructose in blood and urine. J. biol. Chem. 107, 15-22.

Steel, R.G.D. \& Torrie, J.H. (1960) Principles and Procedures of Statistics. McGraw-Hill Book Co., Inc., New York.

Warner, C.M., Rothschild, M.F., Ford, S.P., Lie, W.R. \& Schwartz, N.K. (1986) Detection of major histocompatibility complex (MHC) antigens on preimplantation pig embryos. Biol. Reprod. 34, Suppl. 1, 179, Abstr.

Wrathall, A.E. (1971) Prenatal survival in pigs. I. Ovulation rate and its influence on prenatal survival in pigs. Review Series No.9. Commonwealth Agricultural Bureau, Farnham Royal, Slough SL2 3BN, England.

Zavy, M.T., Clark, W.R., Sharp, D.C., Roberts, R.M. \& Bazer, F.W. (1982) Comparison of glucose, fructose, ascorbic acid and glucose phosphate isomerase enzymatic activity in uterine flushings from nonpregnant and pregnant gilts and pony mares. Biol. Reprod. 32, $1147-1158$.

Received 23 October 1987 